ISSN 1678-3921

Journal homepage: www.embrapa.br/pab

For manuscript submission and journal contents, access: www.scielo.br/pab

\section{Genetic control of thermoinhibition tolerance in lettuce seeds}

\begin{abstract}
The objective of this work was to assess the genetic control of tolerance to thermoinhibition in lettuce (Lactuca sativa) seeds. Seeds of the $\mathrm{F}_{1}$, $\mathrm{F}_{2}$, and $\mathrm{F}_{2: 3}$ generations derived from the cross between cultivars Everglades (tolerant to thermoinhibition) and Verônica (sensitive to thermoinhibition) were used, besides seeds from the parents. Seed germination tests were conducted in a completely randomized design, with four replicates of each parent, eight of $F_{1}$, and four of each of the $26 F_{2: 3}$ progenies. The mean of the $\mathrm{F}_{2}$ population was considered as the mean of the sample of the 26 progenies. The genetic control of thermoinhibition tolerance in lettuce seeds is attributed to one or a few genes. The additive effects are more expressive than the nonadditive ones, and narrow-sense heritability is relatively high, allowing the prediction of success in selection.
\end{abstract}

Index terms: Lactuca sativa, genetic variability, heritability, seed germination.

Daniele Fátima de Oliveira(1) (1D, Pedro Yuri Cavasin ${ }^{(1 凶)(i D,}$ Sylmara Silva(1) (D), Natália Souza Oliveira(1) (iD, Cleiton Lourenço de Oliveira(1) (iD) and Luiz Antonio Augusto Gomes ${ }^{(2)}$ (D)

(1) Universidade Federal de Lavras, Aquenta Sol, CEP 37200-900 Lavras, MG, Brazil. E-mail: oliveiradfmg@gmail.com, pedrocavasin91@gmail.com sylmara-silva@hotmail.com, natalia.agro@yahoo.com.br, cleiton.oliveira@ufla.br

(2) Universidade Federal de Uberlândia, Campus Patos de Minas, Avenida Getúlio Vargas, no 230, Centro, CEP 38700-128 Patos de Minas, MG, Brazil.

E-mail: laagomes@ufla.br

$\bowtie$ Corresponding author

Received

November 12, 2020

Accepted

July 27, 2021

How to cite

OLIVEIRA, D. F. de; CAVASIN, P.Y.; SILVA, S.; OLIVEIRA, N.S.; OLIVEIRA, C.L. de; GOMES, L.A.A. Genetic control of thermoinhibition tolerance in lettuce seeds. Pesquisa Agropecuária Brasileira, v.56, e02337, 2021. DOI: https://doi.org/10.1590/S1678-3921. pab2021.v56.02337.

\section{Controle genético da tolerância à termoinibição em sementes de alface}

Resumo - O objetivo deste trabalho foi determinar o controle genético da tolerância à termoinibição em sementes de alface (Lactuca sativa). Utilizaram-se sementes das gerações $F_{1}, F_{2}$ e $F_{2: 3}$ oriundas do cruzamento entre as cultivares Everglades (tolerante à termoinibição) e Verônica (sensível à termoinibição), além de sementes dos próprios genitores. Realizaram-se testes de germinação das sementes em delineamento completamente casualizado, com quatro repetições para cada um dos genitores, oito para a $F_{1}$ e quatro para cada uma das 26 progênies $F_{2: 3}$. A média da população $F_{2}$ foi considerada como a média da amostra das 26 progênies. O controle genético da tolerância à termoinibição em sementes de alface é atribuído a um ou poucos genes. Os efeitos aditivos são mais expressivos do que os não aditivos, e a herdabilidade no sentido restrito é relativamente alta, o que permite antever sucesso com a seleção.

Termos para indexação: Lactuca sativa, variabilidade genética, herdabilidade, germinação de sementes.

\section{Introduction}

Lettuce is a leafy plant of great economic importance in Brazil and is cultivated in almost all the regions of the country (Silva et al., 2019). Temperature can act directly or indirectly on germination, affecting seed dormancy and viability (Deng \& Song, 2012). In addition, germination problems can cause poor quality seeds and a delay in 
seedling production, resulting in low yields and direct losses for farmers (Bufalo et al., 2012; Nascimento et al., 2012).

In general, in autogamous species, the estimation of genetic and phenotypic parameters and the testing of the hypothesis of monogenic inheritance have been carried out using data from plants of the $\mathrm{P}_{1}$ and $\mathrm{P}_{2}$ contrasting lines, of the $F_{1}$ (cross between $\mathrm{P}_{1}$ and $\mathrm{P}_{2}$ ) and $F_{2}$ (self-fertilization of $F_{1}$ plants) generations, and of $\mathrm{RC}_{1}$ (backcrosses between $\mathrm{F}_{1}$ and $\mathrm{P}_{1}$ individuals) and $\mathrm{RC}_{2}$ (backcrosses between $\mathrm{F}_{1}$ and $\mathrm{P}_{2}$ individuals) (Matos Filho et al., 2014). In interparietal crosses between contrasting genitors, it is possible to identify hybrids by phenotypic characters, although this is better observed in adult plants (Silva et al., 2005). Specifically in lettuce, it is difficult to ensure seeds derived from backcrosses, since these generations have intermediate phenotypic characteristics. In this case, the option is usually to use seeds of $\mathrm{F}_{2: 3}$ progenies to confirm $\mathrm{F}_{2}$ segregation (Carvalho Filho et al., 2011).

In the literature, there are few known reports on thermotolerant lettuce genotypes. Argyris et al. (2011), for example, mentioned the UC96US23 accession of Lactuca serriola L., which is capable of germinating at temperatures close to $37^{\circ} \mathrm{C}$, whereas Yoong et al. (2016) referred to the primitive PI251246 accession of Lactuca sativa L., with seed germination capacity even at temperatures above $33^{\circ} \mathrm{C}$; this latter accession was obtained by crossing UC96US23 with cultivar Salinas (Schwember \& Bradford, 2010). Catão et al. (2014) and Almeida et al. (2019) identified cultivar Everglades of L. sativa as tolerant to thermoinhibition.

Thestudy of the genetic control of the thermotolerance trait is important for the implementation of breeding programs. This way, it is possible to better understand the behavior of generations obtained from the crossing of thermosensitive and thermotolerant genotypes, as well as to establish more suitable breeding methods for lettuce.

The objective of this work was to assess the genetic control of tolerance to thermoinhibition in lettuce seeds.

\section{Materials and Methods}

The used lettuce (L. sativa) seeds were produced in a protected environment, at the experimental facilities of Center for Development and Technology Transfer of Fazenda Palmital, belonging to Universidade Federal de Lavras, located in the municipality of Ijaci, in the

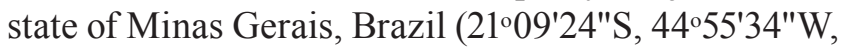
at $831 \mathrm{~m}$ of altitude).

Two lettuce cultivars, Everglades and Verônica, were crossed. The Everglades cultivar has smooth, tender leaves and is tolerant to thermoinhibition (Catão et al., 2014; Almeida et al., 2019), while Verônica has wavy, puckered, and loose leaves and is sensitive to thermoinhibition (Kano et al., 2011; Villela et al., 2010).

To obtain the seeds, cultivars Everglades and Verônica were initially sown in polystyrene trays with 128 cells, each of them with three seeds and filled with an organomineral substrate. After germination and seedling emergence, thinning was done, leaving only one plant per cell.

The seedlings were placed on concrete benches, with a $30 \%$ shading screen. Then, the seedlings were irrigated as needed and, 25 days after germination, they were transplanted into $10 \mathrm{~L}$ pots, containing a 2:1:1 mixture of soil, sand, and organic compost, respectively.

During the conduction of the plants until seed harvesting, spraying, fertilization, and irrigation were performed, according to the needs of the culture (Ribeiro et al., 1999).

At the time of flowering, crossings were carried out in the morning, with the emasculation of the flowers of the 'Everglades' female parent before sunrise, at 4:00 a.m., to avoid cutting the stigmas. The flowers from the 'Verônica' male parent were collected for pollination after flower opening at around 8:30 a.m.

The stigmas were pollinated after being fully developed, i.e., when they became bifid with open flowers. Pollination was done manually with an open flower of the Verônica cultivar, which was rubbed directly on the stigmas of the emasculated flower of the female parent. After their development and maturation, seeds were harvested and identified as $F_{1}$. The $F_{1}$ seeds were sown and cultivated as previously described, to generate the $F_{2}$ and $F_{2: 3}$ seeds.

After obtaining the seeds of the $F_{2}$ generation, new seeds from all generations were needed for the study, but they had to be collected at the same time and under the same conditions. This was done to avoid any effect of different environmental conditions, especially temperature at the time of seed formation.

These seeds were sown simultaneously with those of the parents and of the $F_{1}$ and $F_{2}$ generations, 
and were harvested 15 days after anthesis, at the physiological maturity point (Clemente et al., 2013). During the seed production process, the maximum and minimum average temperatures were estimated, being, respectively, 44.3 and $31.5^{\circ} \mathrm{C}$.

Afterwards, the seeds from the 'Everglades' and 'Verônica' parents and from the $\mathrm{F}_{1}$ generation, with $\mathrm{F}_{2}$ in bulk, were collected. The $26 \mathrm{~F}_{2: 3}$ progenies were also collected individually. The purity of the $\mathrm{F}_{1}$ seeds was assessed by sowing the parents and the $\mathrm{F}_{1}$ generation in a polypropylene tray, in which the occurrence of contamination was determined by differences in leaf edge: frilled and curled edges for cultivar Verônica (Silva et al., 2008), smooth edges for cultivar Everglades (Catão et al., 2016), and intermediate edges for $F_{1}$ (Silva et al., 2005). The seeds of the $F_{2: 3}$ progeny were used to detect the proportion of segregation observed in $\mathrm{F}_{2}$, which allows inferring about the number of genes involved in the trait (Ramalho et al., 2012).

For the first count and germination (\%) tests (Brasil, 2009), an experiment was carried out in a completely randomized design with replicates of 50 seeds per treatment, with four replicates of each parent, eight replicates of $F_{1}$, and four replicates of each of the $26 F_{2: 3}$ progenies, totaling 120 plots. To estimate the mean of the $F_{2}$ population, the sample mean of the 26 progenies was used.

For the germination tests, the seeds were spread on blotting paper moistened with distilled water and placed in $\mathrm{BOD}$ chambers, at $35^{\circ} \mathrm{C}$, under a 12 hour photoperiod (Brasil, 2009). The first and second germination counts were carried out four and seven days after sowing, respectively. To ensure that the remaining seeds were in thermoinhibition and not thermodormancy, temperature was reduced to $20^{\circ} \mathrm{C}$ after the second count. New counts were done four and seven days later, in order to assess the thermoinhibition effect, using seed germination data at $20^{\circ} \mathrm{C}$. Both counts were performed as recommended by Brasil (2009).

After the test was completed, the seeds that failed to germinate, even at $20^{\circ} \mathrm{C}$, had their integuments removed and were subjected to the tetrazolium test (2,3,5-triphenyltetrazolium chloride) (Brasil, 2009). The results were expressed as percentage of viable seeds.

Data were subjected to the analysis of variance according to the F-test using the Sisvar software
(Ferreira, 2011), and the R, version 3.1.3 (R Core Team, 2015), software was used to estimate the components of mean and variance.

The mean components, mean estimator (m), deviations of the homozygote from the mean (â), and deviation of the heterozygote from the mean ( $\hat{d})$ were estimated using the method of the weighted least squares, considering the additive and dominant model without epistasis (Ramalho et al., 2012), according to the expression:

$$
\begin{aligned}
& \widehat{\beta}=\left(\mathrm{C}^{\prime} \mathrm{NS}^{-1} \mathrm{C}\right)^{-1}\left(\mathrm{C}^{\prime} \mathrm{NS}^{-1} \mathrm{Y}\right) \\
& \widehat{\beta}=\left|\begin{array}{c}
\mathrm{m} \\
\hat{\mathrm{a}} \\
\hat{\mathrm{d}}
\end{array}\right| \quad \mathrm{C}=\left|\begin{array}{ccc}
1 & -1 & 0 \\
1 & 1 & 0 \\
1 & 0 & 1 \\
1 & 0 & 0.5
\end{array}\right| \quad \mathrm{Y}=\left|\begin{array}{c}
\overline{\mathrm{P}}_{1} \\
\overline{\mathrm{P}}_{2} \\
\overline{\mathrm{F}}_{1} \\
\overline{\mathrm{F}}_{2}
\end{array}\right| \\
& \mathrm{N}=\left|\begin{array}{llll}
\mathrm{n}_{1} & 0 & 0 & 0 \\
0 & \mathrm{n}_{2} & 0 & 0 \\
0 & 0 & \mathrm{n}_{3} & 0 \\
0 & 0 & 0 & \mathrm{n}_{4}
\end{array}\right| \quad \mathrm{S}=\left|\begin{array}{llll}
\mathrm{VP}_{1} & 0 & 0 & 0 \\
0 & \mathrm{VP}_{2} & 0 & 0 \\
0 & 0 & \mathrm{VF}_{1} & 0 \\
0 & 0 & 0 & \mathrm{VF}_{2}
\end{array}\right|
\end{aligned}
$$

where $\hat{\beta}$ is the vector of the estimates, in which $m$ is the mean estimator, $\hat{a}$ is the estimator of deviations of the homozygote from the mean, and $\hat{d}$ is the deviation of the heterozygote from the mean; $\mathrm{C}$ is the model matrix referring to populations $\mathrm{P}_{1}, \mathrm{P}_{2}, \mathrm{~F}_{1}$, and $\mathrm{F}_{2}$; $\mathrm{Y}$ is the vector of the means of each population; $\mathrm{N}$ is the matrix associated with the number of plants evaluated, in which $\mathrm{n}_{1}, \mathrm{n}_{2}, \mathrm{n}_{3}$, and $\mathrm{n}_{4}$ are the number of plants from populations $\mathrm{P}_{1}, \mathrm{P}_{2}, \mathrm{~F}_{1}$, and $\mathrm{F}_{2}$, respectively; and $\mathrm{S}$ is the matrix of variances associated with the populations, in which $\mathrm{VP}_{1}, \mathrm{VP}_{2}, \mathrm{VF}_{1}$, and $\mathrm{VF}_{2}$ are the variances among the plants of generations $\mathrm{P}_{1}, \mathrm{P}_{2}, \mathrm{~F}_{1}$, and $\mathrm{F}_{2}$, respectively.

The components of phenotypic variance $-\hat{\mathrm{V}}_{\mathrm{E}}, \hat{\mathrm{V}}_{\mathrm{A}}$, and $\hat{V}_{D}$ - were estimated using the weighted least squares method, according to Ramalho et al. (2012) and Cruz et al. (2012), considering the same populations and according to the following expression:

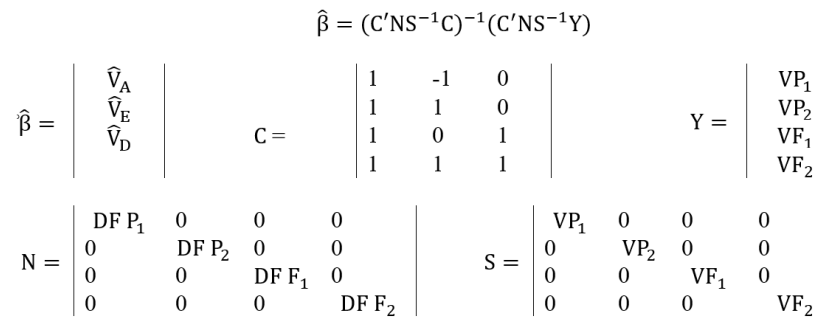

where $\hat{\beta}$ is the vector of the estimates, in which $\hat{V}_{\mathrm{A}}$, is the additive genetic variance, $\hat{V}_{\mathrm{E}}$, is the environmental variance, and $\hat{V}_{D}$, is the dominance variance; $C$ is the model matrix; $\mathrm{Y}$ is the vector of the variances estimated 
from the observations of the different populations; $\mathrm{N}$ is the matrix constructed according to the model matrix, with DF corresponding to the degrees of freedom associated with each source of variation; and $\mathrm{S}$ is the weighting matrix that corresponds to the variances observed for each population.

Narrow-sense heritability $\left(\mathrm{h}_{\mathrm{r}}^{2}\right)$ was obtained for the trait germination percentage, using the estimates of the variance components:

$$
h_{r}^{2}=\frac{\hat{V}_{A}}{\hat{V}_{A}+\hat{V}_{D}+\hat{V}_{E}}
$$

Accuracy (rgg') was estimated by the formula:

$\operatorname{rgg}^{\prime}=\sqrt{ } 1-(1 / F)$

where $\mathrm{F}$ (Snedecor) is the value of the variance ratio for the effects of treatments associated with the analysis of variance (Resende, 2002).

Finally, incomplete dominance was given by d, which was obtained by the following formula:

$$
\mathrm{d}=\mathrm{mF}_{1} \frac{\left(\mathrm{P}_{1}+\mathrm{P}_{2}\right)}{2}
$$

where $\mathrm{m}$ is the mean of the $\mathrm{F}_{1}$ generation.

\section{Results and Discussion}

Initially, the F-test of the analysis of variance showed differences among the genotypes at $1 \%$ probability, confirming variability for the trait thermoinhibition tolerance in seeds - germinated at $35^{\circ} \mathrm{C}-$ of the Everglades and Verônica lettuce cultivars and of the generations derived from the cross between them (Table 1).

The Everglades and Verônica cultivars, corresponding to genotypes 1 and 2, respectively, had a germination percentage of 93 and $17 \%$ at $35^{\circ} \mathrm{C}$ (Figure 1). These results are indicative of the divergence between both parents for thermoinhibition tolerance, which may be attributed to the activity of the endo$\beta$-mannanase enzyme that was greater in Everglades than in the thermosensitive cultivar. Therefore, the highest germination percentage in Everglades may be explained by the higher enzymatic activity in the seeds of this cultivar (Catão et al., 2014, 2018).

Compared with the parents, generations $F_{1}$, represented by genotype 3 , and $\mathrm{F}_{2}$, represented by genotype 4 , had intermediate germination percentages of 81 and $65 \%$, respectively, indicating that the predominant allelic interaction, which conditions thermoinhibition tolerance, is additive. Additive allelic interactions are common for several traits in autogamous species (Baldissera et al., 2014).

The analysis of variance showed a significant difference for germination among the plants of generation $\mathrm{F}_{2}\left(\mathrm{~F}_{2: 3}\right.$ progenies) (Table 2$)$. The germination means of the $\mathrm{F}_{2: 3}$ progenies, corresponding to the 26 genotypes numbered from 5 to 30 (Figure 1), ranged from 9 to $96 \%$, with an overall mean of $65 \%$, which is considered the mean of the $\mathrm{F}_{2}$ generation. This variation in germination within the progenies is due to segregation, which is fundamental for the selection of genetic parameters of interest, such as heritability, reflecting the proportion of phenotypic variance that can be inherited (Baldissera et al., 2014).

Additive effects $(\hat{a}=38.78)$ are more important than nonadditive ones $(\hat{\mathrm{d}}=26.28)$ for the thermoinhibition

\begin{tabular}{|c|c|c|c|c|c|}
\hline Source of variation & $\mathrm{DF}$ & SS & MS & F-test & Mean \\
\hline Genotype & 29 & 110703.5577 & 3817.3641 & $62.99 * *$ & - \\
\hline Residual error & 90 & 5454.3506 & 60.6039 & - & - \\
\hline Total & 119 & 116157.9083 & - & - & - \\
\hline Within parent 1 & 3 & 36.6656 & 12.2219 & - & 93 \\
\hline Within parent 2 & 3 & 212.5025 & 70.8342 & - & 17 \\
\hline Within $\mathrm{F}_{1}$ & 7 & 295.6821 & 42.2403 & - & 81 \\
\hline Within $\mathrm{F}_{2}$ & 103 & 100975.0404 & 980.3402 & - & 65 \\
\hline CV (\%) & & & & - & 11.89 \\
\hline Overall mean & & & & - & 66 \\
\hline
\end{tabular}

Table 1. Analysis of variance of the germination percentage of lettuce seeds (Lactuca sativa) at $35^{\circ} \mathrm{C}^{(1)}$.

${ }^{(1)} \mathrm{DF}$, degree of freedom; SS, sum of squares; MS, mean square; and CV, coefficient of variation. **Significant at $1 \%$ probability. 
tolerance trait (Table 3). Since the additive effect is related to characteristics that can be passed on to subsequent generations, its greater magnitude means that a large part of the traits that confer thermotolerance will be passed on to other generations (Labroo et al., 2021). The same happens for resistance to the Meloidogyne javanica nematode in lettuce seeds, considering the predominance of the additive effect in relation to the nonadditive effects (Maluf et al., 2002).

The estimate of the mean degree of dominance (MDD) indicates a greater dominance regarding thermotolerance (Table 3), which, however, is still lower than that of the additive effects found to control this characteristic (Cruz et al., 2012). According to Cheverud \& Routman (1995), the biologically dominant or epistatic gene action is largely captured by statistical average effects, because both statistical dominance and epistasis are residual deviations from

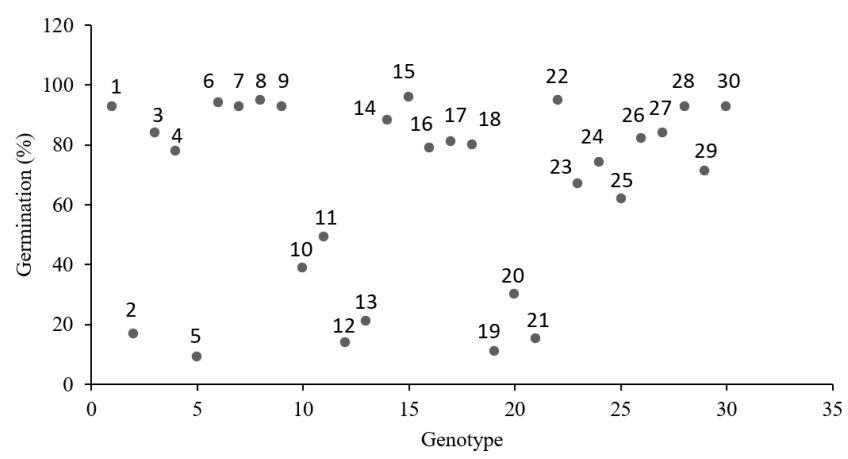

Figure 1. Dispersion of the germination percentage of lettuce (Lactuca sativa) seeds at $35^{\circ} \mathrm{C}$ for: cultivars Everglades (1) and Verônica (2) as parents; generations $\mathrm{F}_{1}$ (3) and $F_{2}(4)$; and $26 \mathrm{~F}_{2: 3}$ progenies (5 to 30 ).

Table 2. Analysis of variance of the germination percentage of lettuce (Lactuca sativa) seeds collected from plants of generation $\mathrm{F}_{2}$ (progenies $\mathrm{F}_{2: 3}$ of 'Everglades' $\mathrm{x}$ 'Verônica') at $35^{\circ} \mathrm{C}^{(1)}$.

\begin{tabular}{lcrrrc}
\hline $\begin{array}{l}\text { Source of } \\
\text { variation }\end{array}$ & DF & SS & MS & F-test & $\begin{array}{r}\text { P-value } \\
>\text { F-test }\end{array}$ \\
\hline $\begin{array}{l}\text { Plants of } \\
\text { generation } \mathrm{F}_{2}\end{array}$ & 25 & $95,978.2286$ & $3,839.1291$ & $59.93^{* *}$ & 0.00 \\
Error & 78 & $4,996.8119$ & 64.0617 & & \\
Total & 103 & $100,975.0404$ & & & \\
\hline CV $(\%)$ & 12.29 & & & & \\
\hline
\end{tabular}

(1) DF, degree of freedom; SS, sum of squares; MS, mean square; and CV, coefficient of variation. **Significant at $1 \%$ probability. these effects. Since lettuce is an autogamous species, with a high cleistogamous effect, the high value of the MDD estimate is an important information for the genetic improvement of the crop.

The dominant additive model without epistasis explained the observed means, since the chi-square test was not significant and the model fit $\left(\mathrm{R}^{2}\right)$ estimate between the observed and estimated means was practically 1.0 (Table 4). Likewise, high values of $\mathrm{R}^{2}$ were verified by Oliveira et al. (2019) in a study about pigment genetic parameters and agronomic traits in lettuce, in which the authors also proposed a dominant additive model. Therefore, when superior genotypes for resistance to thermotolerance in lettuce seeds are selected in one generation, the next would have similar results regarding this trait.

The estimate of heritability in the narrow sense was also high (Table 4). This means that the phenotypic variability of thermoinhibition can be attributed to additive variance, that is, to the proportion of genetic variance that can be fixed with selection. Furthermore, it has been reported that the studied trait must be controlled by few genes (Ramalho et al., 2012). Therefore, selection based on phenotype is promising for breeding programs that aim to obtain thermotolerant lettuce cultivars, since the genetic control of this trait is known and the additive effects can be fixed.

Table 3. Estimation of the mean components of the germination percentage of lettuce (Lactuca sativa) seeds at $35^{\circ} \mathrm{C}^{(1)}$.

\begin{tabular}{lccc}
\hline Model parameter & Estimate & Standard error & Probability $>|\mathrm{t}|$ \\
\hline $\mathrm{m}$ & 53.98 & 8.38 & 0.0000 \\
$\hat{\mathrm{a}}$ & 38.78 & 8.63 & 0.0000 \\
$\hat{\mathrm{d}}$ & 26.28 & 12.60 & 0.0199 \\
$\mathrm{MDD}$ & 0.68 & - & - \\
\hline \multirow{2}{*}{ Population } & & \multicolumn{2}{c}{ Germination $(\%)$} \\
\cline { 2 - 4 } & & Observed & Estimated \\
\hline 'Everglades' & 92.92 & 92.76 \\
'Verônica' & & 16.14 & 15.19 \\
$\mathrm{~F}_{1}$ & & 80.82 & 80.26 \\
$\mathrm{~F}_{2}$ & & 65.12 & 67.12 \\
\hline$\chi^{2}$ & 0.54 & $\mathrm{p}(0.4624)$ \\
$\mathrm{R}^{2}$ & & 99.99 & - \\
\hline
\end{tabular}

${ }^{(1)} \mathrm{m}$, mean estimator; â, deviations of the homozygote from the mean; $\hat{d}$, deviation of the heterozygote from the mean; MDD, values of the mean degree of dominance; $F_{1}$ and $F_{2}$, plant generations; $\chi^{2}$, chi-square; and $\mathrm{R}^{2}$, model fit. 
Table 4. Estimation of the variance components of the germination percentage of lettuce (Lactuca sativa) seeds at $35^{\circ} \mathrm{C}$.

\begin{tabular}{|c|c|c|c|c|}
\hline Parameter $^{(1)}$ & Estimate & Error & t-test & Probability $\mathrm{t}>0$ \\
\hline Genetic variance & 966.423846 & & & \\
\hline Additive variance & 938.0999 & 15.289921 & 61.35414 & $1.5879 \mathrm{e}-75$ \\
\hline Dominance variance & 28.323946 & 2.3835914 & 11.88289 & $1.9405 \mathrm{e}-20$ \\
\hline$h^{2}$ & 98.5805 & & & \\
\hline rgg' & 0.99 & & & \\
\hline $\mathrm{R}^{2}$ & 97.318982 & 0 & 0 & 0 \\
\hline$\chi^{2}$ & 1.662231 & 0 & 0 & 0 \\
\hline
\end{tabular}

${ }^{(1)} h^{2}$, heritability; rgg', accuracy; $\mathrm{R}^{2}$, model fit; and $\chi^{2}$, chi-square.

The germination percentage, at $35^{\circ} \mathrm{C}$, for the $\mathrm{F}_{1}$ generation $(81 \%)$ was considered intermediate, between those obtained for the 'Everglades' (93\%) and 'Verônica' (17\%) female and male parents, respectively, but tending to approach that of the tolerant mother, as it was higher than the parental mean (55\%) (Table 3). This result differs from incomplete dominance, possibly due to a maternal effect, as the $F_{1}$ mean is close to that of the female parent (Ramalho et al., 2012).

The deviation of the heterozygote from the parental average () was 26.28 , corresponding to the deviation of the mean of the $F_{1}$ generation $(81 \%)$ from the mean of the two parents (55\%) (Table 3), indicating incomplete dominance. When the additive effects for a trait are high in a given cross, the mean of the parents does not differ from that of the progeny, differently from the results found in the present work. However, with nonadditive effects (dominance and/or epistasis) in the control of a characteristic, the mean of the parents differs from that of the $F_{1}$ progeny (Allard, 1999). In addition, there is a possibility of maternal effect in the $F_{1}$ generation, as the germination percentage is close to that of the 'Everglades' female parent (Table 3).

It was found that there was a predominance of the gene action of additivity in controlling the thermoinhibition trait. However, there is also the possibility of the gene action of nonadditive effects, such as the maternal effect. Therefore, to detect the action of the maternal effect, it is necessary to carry out reciprocal crossings (Nascimento et al., 2016).

\section{Conclusions}

1. Thermoinhibition tolerance in lettuce (Lactuca sativa) seeds is a trait controlled by one or a few genes.
2. Additive effects are more significant than nonadditive effects for the trait thermoinhibition tolerance in lettuce seeds.

3. Narrow-sense heritability is relatively high for the trait thermoinhibition tolerance in lettuce seeds, allowing the prediction of selection gain.

4. Conventional breeding of lettuce aiming at thermoinhibition tolerance is feasible from crosses between contrasting genotypes.

\section{Acknowledgments}

To Conselho Nacional de Desenvolvimento Científico e Tecnológico (CNPq) and to Fundação de Amparo à Pesquisa do Estado de Minas Gerais (Fapemig), for scholarships granted; and to Coordenação de Aperfeiçoamento de Pessoal de Nível Superior (Capes), for financing, in part, this study (Finance Code 001).

\section{References}

ALLARD, R.W. Principles of plant breeding. $2^{\text {nd }}$ ed. New York: J. Wiley \& Sons, 1999. 254p.

ALMEIDA, F.A. de; SILVA-MANN, R.; SANTOS, H.O. dos; PEREIRA, R.W.; BLANK, A.F. Germination temperatures affect the physiological quality of seeds of lettuce cultivars. Bioscience Journal, v.35, p.1143-1152, 2019. DOI: https://doi.org/10.14393/ BJ-v35n4a2019-42196.

ARGYRIS, J.; TRUCO, M.J.; OCHOA, O.; MCHALE, L.; DAHAL, P.; VAN DEYNZE, A.; MICELMORE, R.W.; BRADFORD, K.J. A gene encoding an abscisic acid biosynthetic enzyme (LsNCED4) collocates with the high temperature germination locus Htg6.1 in lettuce (Lactuca sp.). Theoretical and Applied Genetics, v.122, p.95-108, 2011. DOI: https://doi.org/10.1007/s00122-010-1425-3.

BALDISSERA, J.N. da C.; VALENTINI, G.; COAN, M.M.D.; GUIDOLIN, A.F.; COIMBRA, J.L.M. Fatores genéticos 
relacionados com a herança em populações de plantas autógamas. Revista de Ciências Agroveterinárias, v.13, p.181-189, 2014.

BRASIL. Ministério da Agricultura, Pecuária e Abastecimento. Regras para análise de sementes. Brasília, 2009. 399p.

BUFALO, T.; AMARO, A.C.E; ARAÚJO, H.S; de CORSATO, J.M; ONO, E.O; FERREIRA, G; RODRIGUES, J.D. Períodos de estratificação na germinação de sementes de alface (Lactuca sativa L.) sob diferentes condições de luz e temperatura. Semina: Ciências Agrárias, v.33, p.931-940, 2012. DOI: https://doi.org/10.5433/1679-0359.2012v33n3p931.

CARVALHO FILHO, J.L.S. de; GOMES, L.A.A; MALUF, W.R.; OLIVEIRA, R.R.; COSTA, D.S.; FERREIRA, S.; MONTEIRO, A.B.; CARVALHO, R.R. da C. e. Resistance to Meloidogyne incognita race 1 in the lettuce cultivars Grand Rapids and Salinas-88. Euphytica, v.182, p.199-208, 2011. DOI: https://doi.org/10.1007/s10681-011-0429-7.

CATÃO, H.C.R.M.; GOMES, L.A.A.; GUIMARÃES, R.M.; FONSECA, P.H.F.; CAIXETA, F.; GALVÃO, A.G. Physiological and biochemical changes in lettuce seeds during storage at different temperatures. Horticultura Brasileira, v.36, p.118-125, 2018. DOI: https://doi.org/10.1590/S0102-053620180120.

CATÃO, H.C.R.M.; GOMES, L.A.A.; GUIMARÃES, R.M.; FONSECA, P.H.F.; CAIXETA, F.; MARODIN, J.C. Physiological and isozyme alterations in lettuce seeds under different conditions and storage periods. Journal of Seed Science, v.38, p.305-313, 2016. DOI: https://doi.org/10.1590/2317-1545v38n4163863.

CATÃO, H.C.R.M.; GOMES, L.A.A.; SANTOS, H.O. dos; GUIMARÃES, R.M.; FONSECA, P.H.F.; CAIXETA, F. Aspectos fisiológicos e bioquímicos da germinação de sementes de alface em diferentes temperaturas. Pesquisa Agropecuária Brasileira, v.49, p.316-322, 2014. DOI: https://doi.org/10.1590/S0100204X2014000400010.

CHEVERUD, J.M.; ROUTMAN, E.J. Epistasis and its contribution to genetic variance components. Genetics, v.139, p.1455-1461, 1995. DOI: https://doi.org/10.1093/genetics/139.3.1455.

CLEMENTE, A. da C.S.; GUIMARÃES, R.M.; MARTINS, D.C.; LIMA, A.A.; GOMES, L.A.A.; BALDONI, A. Gene expression associated with the biosynthetic pathway of abscisic acid, gibberellin and ethylene during lettuce seed development. African Journal of Biotechnology, v.12, p.3676-3684, 2013.

CRUZ, C.D.; REGAZZI, A.J.; CARNEIRO, P.C. Modelos biométricos aplicados ao melhoramento genético. 4.ed. Viçosa: UFV, 2012.

DENG, Z.; SONG, S. Sodium nitroprusside, ferricyanide, nitrite and nitrate decrese the thermo-dormancy of lettuce seed germination in a nitric oxide-dependent manner in light. South African Journal of Botany, v.78, p.139-146, 2012. DOI: https://doi.org/10.1016/j.sajb.2011.06.009.

FERREIRA, D.F. Sisvar: a computer statistical analysis system. Ciência e Agrotecnologia, v.35, p.1039-1042, 2011. DOI: https://doi.org/10.1590/S1413-70542011000600001.

KANO, C.; CARDOSO, A.I.I.; VILLAS BÔAS, R.L.; HIGUTI, A.R.O. Germinação de sementes de alface obtidas de plantas cultivadas com diferentes doses de fósforo. Semina: Ciências
Agrárias, v.32,p.591-598, 2011. DOI: https://doi.org/10.5433/16790359.2011v32n2p591.

LABROO, M.R.; STUDER, A.J.; RUTKOSKI, J.E. Heterosis and hybrid crop breeding: a multidisciplinary review. Frontiers in Genetics, v.12, art.643761, 2021. DOI: https://doi.org/10.3389/ fgene.2021.643761.

MALUF, W.R.; AZEVEDO, S.M.; GOMES, L.A.A.; OLIVEIRA, A.C.B. de. Inheritance of resistance to the root-knot nematode Meloidogyne javanica in lettuce. Genetics and Molecular Research, v.1, p.64-71, 2002. DOI: https://doi.org/10.4238/vol11 gmr006.

MATOS FILHO, C.H.A.; GOMES, R.L.F.; FREIRE FILHO, F.R.; ROCHA, M.M.; LOPES, A.C. de A.; NUNES, J.A.R. Herança de caracteres relacionados à arquitetura da planta em feijão-caupi. Ciência Rural, v.44, p.599-604, 2014. DOI: https://doi.org/10.1590/S0103-84782014000400004.

NASCIMENTO, W.M.; ANDRADE, K.P.; FREITAS, R.A.; SILVA, G.O.; BOITEUX, L.S. Germinação de sementes de tomateiro em diferentes temperaturas: variabilidade fenotípica e heterose. Horticultura Brasileira, v.1, p.216-222, 2016. DOI: https://doi.org/10.1590/S0102-053620160000200011.

NASCIMENTO, W.M.; CRODA, M.D.; LOPES, A.C.A. Produção de sementes, qualidade fisiológica e identificação de genótipos de alface termotolerantes. Revista Brasileira de Sementes, v.34, p.510-517, 2012. DOI: https://doi.org/10.1590/ S0101-31222012000300020.

OLIVEIRA, A.H.G. de; MACIEL, G.M.; SIQUIEROLI, A.C.S.; JACINTO, A.C.P.; SILVEIRA, A.J. de; SILVA, E.C. da. Estimates of genetic parameters of pigments and agronomic traits in green and purple lettuce. Ciência e Agrotecnologia, v.43, e013219, 2019. DOI: https://doi.org/10.1590/1413-7054201943013219.

R CORE TEAM. R: a language and environment for statistical computing. Version 3.1.2. Vienna: R Foundation for Statistical Computing, 2015.

RAMALHO, M.A.P.; ABREU, A. de F.B.; SANTOS, J.B. dos; NUNES, J.A.R. Aplicações da genética quantitativa no melhoramento de plantas autógamas. Lavras: Ed. UFLA, 2012. $522 \mathrm{p}$.

RESENDE, M.D.V. de. Genética biométrica e estatística no melhoramento de plantas perenes. Brasília: Embrapa Informação Tecnológica; Colombo: Embrapa Florestas, 2002. 975p.

RIBEIRO, A.C.; GUIMARÃES, P.T.G.; ALVAREZ V., V.H. (Ed.). Recomendações para o uso de corretivos e fertilizantes em Minas Gerais: $5^{\text {a }}$ aproximação. Viçosa: Comissão de Fertilidade do Solo do Estado de Minas Gerais, 1999. 359p.

SCHWEMBER, A.R.; BRADFORD, K.J. A genetic locus and gene expression patterns associated with the priming effect on lettuce seed germination at elevated temperatures. Plant Molecular Biology, v.73, p.105-118, 2010. DOI: https://doi.org/10.1007/s11103-009-9591-X.

SILVA, M.P. da; AMARAL, JÚNIOR, A.T. do; PEREIRA, M.G.; RODRIGUES, R.; DAHER, R.F.; POSSE, S.C.P. Diversidade genética e identificação de híbridos por marcadores RAPD em 
feijão-de-vagem. Acta Scientiarum. Agronomy, v.27 p.531-539, 2005. DOI: https://doi.org/10.4025/actasciagron.v27i3.1466.

SILVA, O.M. dos P. da; LOPES, W. de A.R.; NUNES, G.H. de S.; NEGREIROS, M.Z. de; ESPÍNOLA SOBRINHO, J. Adaptability and phenotypic stability of lettuce cultivars in a semiarid region. Revista Caatinga, v.32, p.552-558, 2019. DOI: https://doi.org/10.1590/1983-21252019v32n228rc.

SILVA, R.R.; GOMES, L.A.A.; MONTEIRO, A.B.; MALUF, W.R.; CARVALHO FILHO, J.L.S. de; MASSAROTO, J.A. Linhagens de alface-crespa para o verão resistentes ao Meloidogyne javanica e ao vírus mosaico-da-alface. Pesquisa Agropecuária Brasileira, v.43, p.1349-1356, 2008. DOI: https://doi.org/10.1590/S0100-204X2008001000013.
VILLELA, R.P.; SOUZA, R.J. de; GUIMARÃES, R.M.; NASCIMENTO, W.M.; GOMES, L.A.A.; CARVALHO, B.O.; BUENO, A.C.R. Produção e desempenho de sementes de cultivares de alface em duas épocas de plantio. Revista Brasileira de Sementes, v.32, p.158-169, 2010. DOI: https://doi.org/10.1590/ S0101-31222010000100018.

YOONG, F.Y.; O’BRIEN, L.K.; TRUCO, M.J.; HUO, H.; SIDEMAN, R.; HAYES, R.; MICHELMORE, R.W.; BRADFORD, K.J. Genetic variation for thermotolerance in lettuce seed germination is associated with temperature-sensitive regulation of Ethylene Response Factor 1 (ERF1). Plant Physiology, v.170, p.472-488, 2016. DOI: https://doi.org/10.1104/pp.15.01251. 